\title{
STRUKTUR BATUAN PENYUSUN DESA PADA'ELO KECAMATAN MALLAWA KABUPATEN MAROS
}

\author{
Musriadi, Ayusari Wahyuni, Sri Zelviani, Trihendriansyah, dan Utari Lestari ${ }^{1}$ \\ 1Jurusan Fisika, Fakultas Sains dan Teknologi, UIN Alauddin Makassar \\ Email: ayusari_wahyuni@uin-alauddin.ac.id, sri.zelviani@uin-alauddin.ac.id
}

\begin{abstract}
This field study aims to look at the structure of rock layers and formations in the Mallawa area of Maros Regency. The method used in this studi is sampling at two points where these two points are estimated to have alignment on the layer. This method is a method of observation, direct measurement, and rock sampling at each point. From . This is obtained by several rock samples from each point which are then tested using water which serves to test the permeability and porosity of rock samples, while the hardness of the rock is tested by giving a scratch on the sample. From the research it was concluded that in general the rock structure in Pada' Elo, Kecamatan. Mallawa, Maros Regency is composed of sedimentary rock formations.
\end{abstract}

Keywords: rock structure, sedimentary rocks.

\section{PENDAHULUAN}

Penelitian ini dilakukan untuk mengetahui struktur lapisan batuan dan formasi pada daerah Mallawa Kabupaten Maros. Struktur lapisan batuan yang bagus otomatis akan berdampak terhadap daya tahan bagunan itu sendiri. Oleh sebab itu, pengetahuan dan pemahaman tentang ilmu geologi utamanya Geologi struktur amat dibutuhkan dalam hal ini.

Secara geografis Kabupaten Maros merupakan salah satu kabupaten yang terletak di provinsi Sulawesi Selatan, yang terletak di bagian barat Sulawesi Selatan antara $5^{\circ}$ 01'04.00'LS dan $119^{\circ} 34^{\prime} 35.0^{\prime \prime}$ BT. Secara administrasi Kabupaten Maros terdiri atas 14 Kecamatan, 80 Desa, dan 23 kelurahan. Dari 14 kecamatan tetsebut satu di anataranya yaitu Desa Pada'elo, Kecamatan Mallawa, Kabupaten Maros. Mallawa yang merupakan lokasi kuliah lapangan. Formasi Mallawa terletak di bagian barat Sulawesi Selatan yang melapis bawahi secara tak selaras formasi Balangbaru dan setempat langi sehingga pada daerah Mallawa terdapat endapan sedimen dan berbentuk seperti aliran sungai atau sering di sebut aluvial fen. Singkapan batuan di daerah Mallawa terdiri dari batu gamping, batu pasir, batu lanau, batu lempung dan batu batu bara.

Geologi struktur itu sendiri merupakan salah satu cabang ilmu geologi yang pembahsannya tentang distribusi tiga dimensi batuan baik bentuk, tekstur maupun keadaan permukaan batuan itu sendiri. 


\section{METODE PENELITIAN}

Studi lapangan ini dilakukan di Desa Pada'elo, Kecamatan Mallawa, Kabupaten Maros., Sulawesi Selatan. Alat yang digunakan untuk pengambiilan data dan sampel pada lokasi adalah palu dan kompas geologi. Metode yang digunakan pada studi lapangan ini ada tiga yaitu pengamatan langsung, pengukuran dan pengambilan sampel batuan pada tiga titik.

Pengambilan data lapisan batuan di Desa Pada'elo yang dilakukan langsung di lokasi. Dimana lokasinya disini merupakan tambang pasir sehingga lapisan batuanya sudah tampak dengan jelas tampa melakukan penggalian lagi sepreti tampak pada gambar 1 .

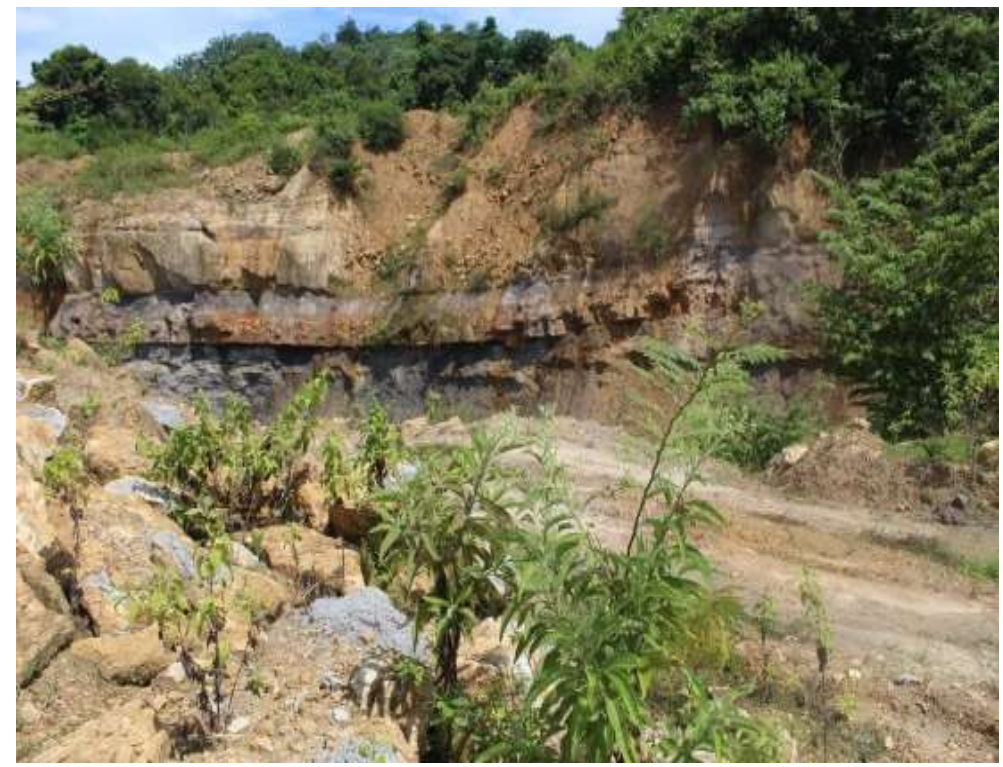

Gambar 1. Penampakan lapisan batuan pada tambang pasir

Setiap lapisan butuan yang diamati diukur ketebalannya mulai dari lapisan terbawah sampai lapisan teratas. Tampilan lapisanya dapat dilihat seperti pada gambar berikut ini. 


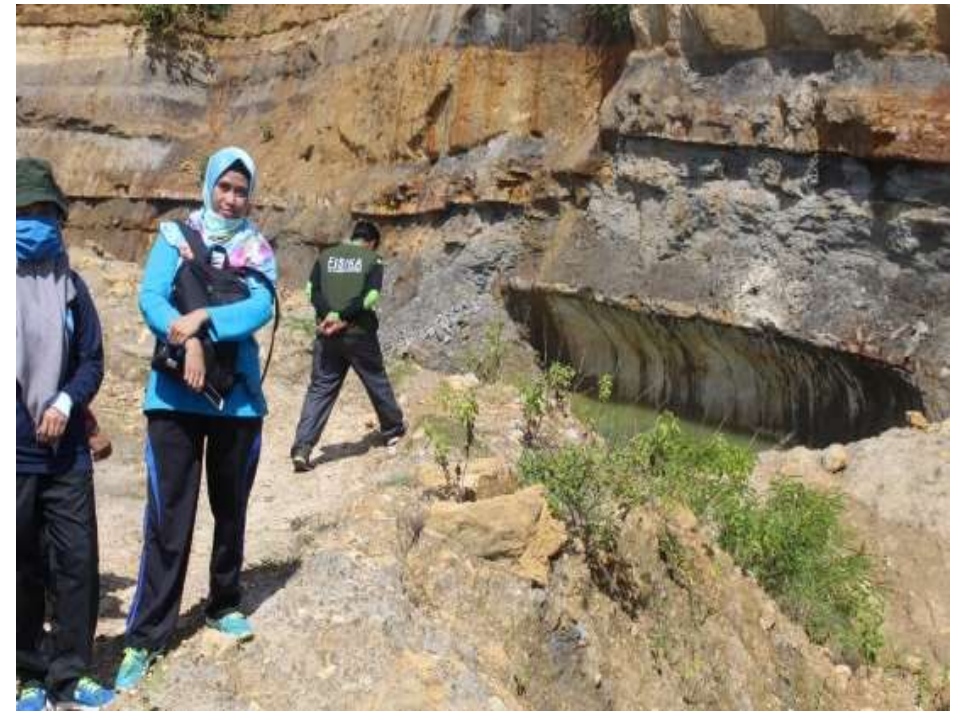

Gambar 2. Tampilan lapisan batuan

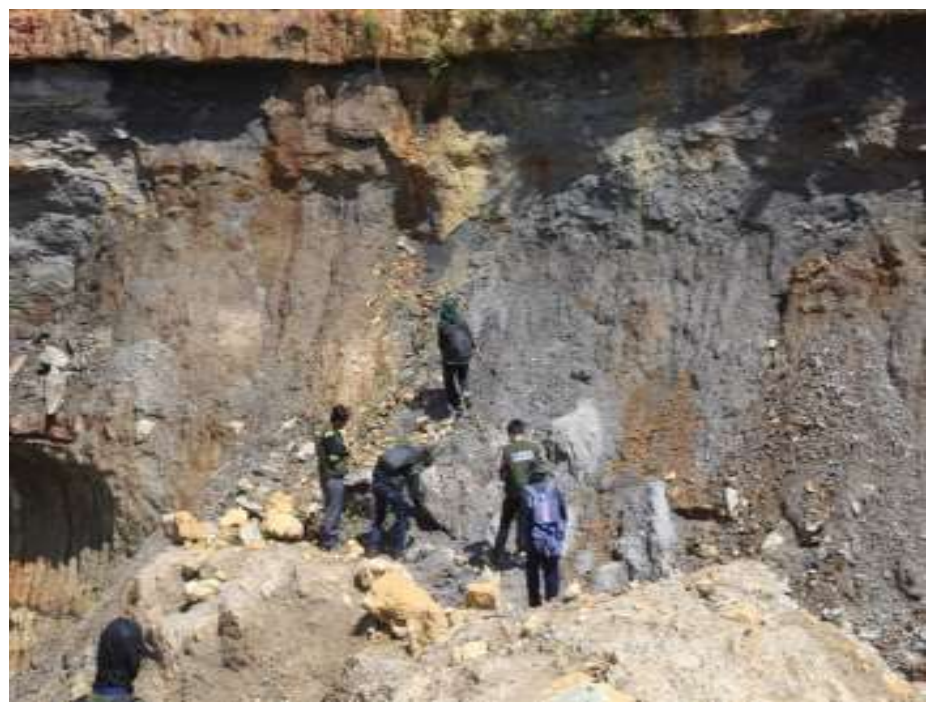

Gambar 3. Pengukuran tebal lapisan batuan

Pengambilan sampel pada tiap titik lokasi pengamatan yang didatangi di ambil sampel batuannya. Sampel batuan yang diperoleh kemudian diuji dengan cara ditetesi air untuk mengetahui permeabilitas dan porositas yang dimiliki sampel batu tersebut. 


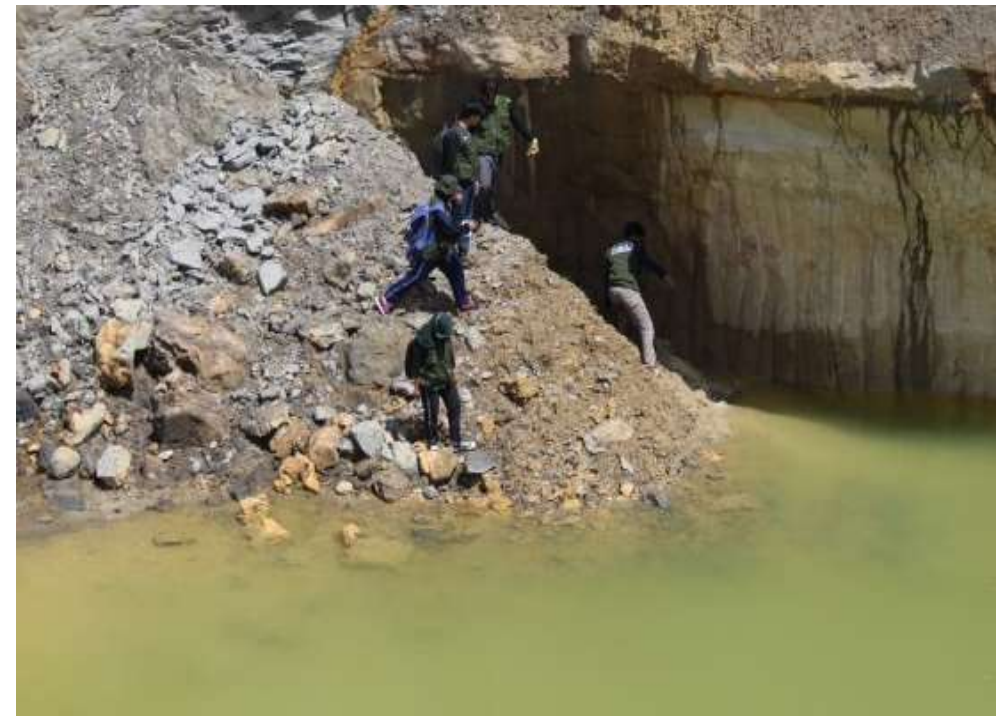

Gambar 4. Proses pengambilan sampel batuan

\section{HASIL PEMBAHASAN}

Berdasarkan lokasi penelitian yang bertitik di Desa Pada'elo Kecamatan Mallawa, Kabupaten Maros, Sulawesi Selatan, Diproleh hasil bahwa desa tersebut tersusun atas batu pasir, batu gamping, batu lempung dan batu serpih.

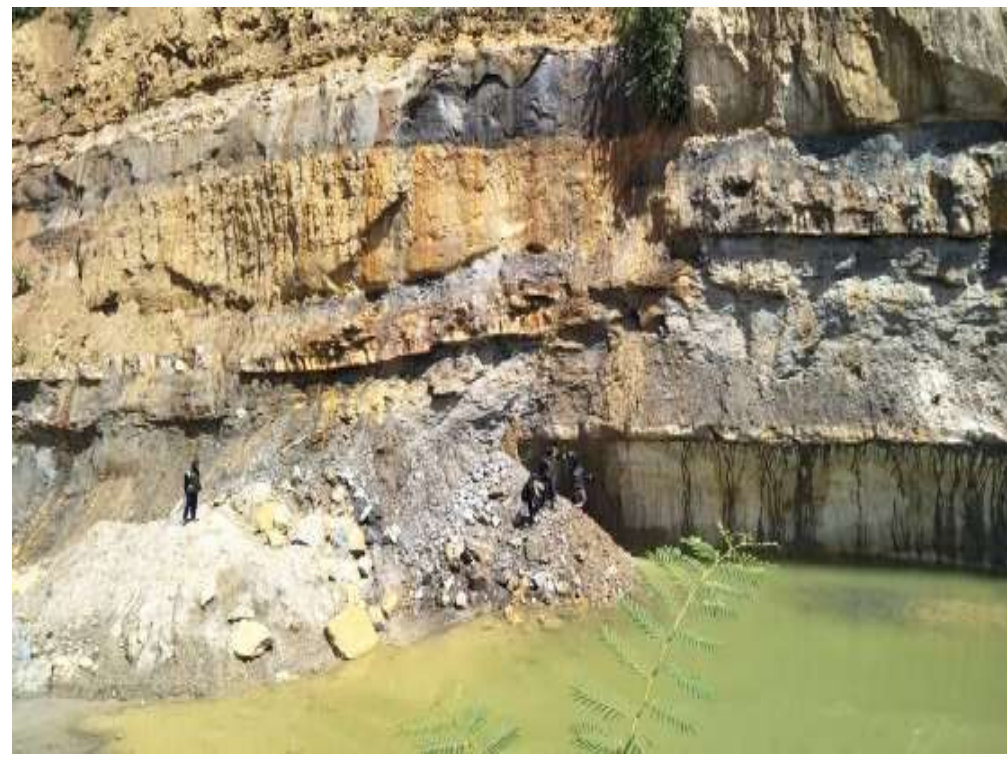

Gambar 5. Susunan batuan pasir, gamping, lempung dan serpih 


\section{Batu pasir}

Batuan pasir atau sandstone meruakan jenis batuan terbentuk dari pelapukan atau pecahan batuan batuan yang lain yang terdiri dari mineral yang berukuran pasir. Batu pasir yang diperoleh pada lokasi pengamatan merupakan batu pasir yang memiliki warna putih yang terbentuk dari kuarsa dan feldspar.

Warna pada batuan pasir yang umunya dijumpai adalah warna coklat muda, coklat, kuning, merah, abu-abu dan putih. Karakteristik warna pada batu pasir bisa diidentikkan dengan daerah tertentu yang merupakan ciri khas warna batuan pada daerah tersebut.

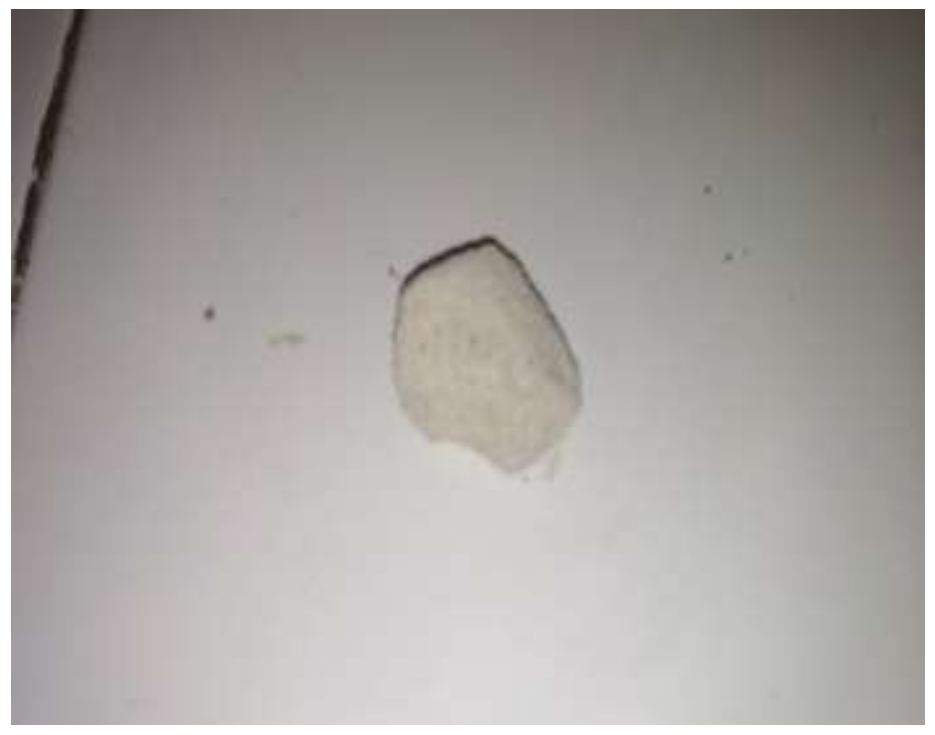

Gambar 6. Sampel batu pasir

Batuan pasir pada lokasi pengamatan berada pada lapisan paling bawah yang tampak pada tambang pasir dengan ketebalan 3 meter. Batu pasir didaerah ini dimanfaatkan oleh masayarakat sebagai bahan bangunan dikarenakan kesamaan butiran dan daya serap yang dimiliknya. Batu pasir pada umumnya terbentuk dari pelapukan atau pengangkutan material batuan lain yang berukuran pasir yang kemuidian mengalami pengendapan dan pengersan. Jika batuan pasir yang terbentuk dekat dengan batuan indukanya, maka batu pasir tersebut akan memiliki komposisi yang mirip batuan induknya.

\section{Batu gamping}

Batu gamping terbentuk melalui beberapa proses baik secara kimiawi, organic maupun secara mekanik. Kebanayak batu gamping yang ada di alam pada dasarnya terbentuk secara organic. Batu gamping yang terbentuk secara organik 
umumnya berasal dari pengen dapan cangkang kerrang, bankai koral, dan cangkang siput.

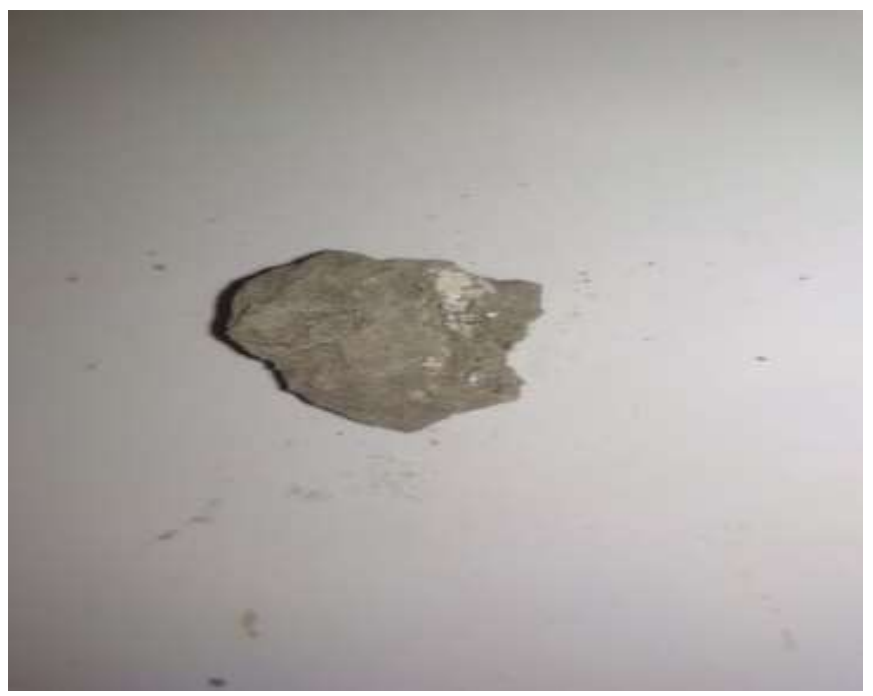

Gambar 7. Sampel batu gamping

Batu Gamping atau Limestone merupakan kelompok batuan sedimen yang umumnya terdiri dari mineral kalsit dan argonik. Sumber utama dari batu gamping pada dasarnya adalah organisme laut. Dimana organisme laut yang mati mengeluarkan shell yeng kemudian terdeposiit kelantai dasar Samudra dan mengalami pengendapan.

Pada lokasi pengamatan batu gamping yang di amati memliki ketebalan lapisan sekitar 1 meter diatas lapisan batu pasir. Pada saat batu di uji dengan di tetesi air daya serap yang dimilikinya kurang bagus dibandingkan batu psair. Batu gamping memiliki tingkat kekerasan dan ikatan antara partikel batuan yang kuat .

\section{Batu serpih}

Sampel batu ketiga yang teridentifikasi adalah butuan serpih. Batu serpih atau shale, disebut juga batu lanau yang termasuk dalam kelompok batuan sedimen. Batuan serpih tersusun atas mineral berat seperti oksida besi, kuarsa, dan karbonat. Selain itu batuan ini juga tersusn atas mineral utama sepeerti illite, kaolinit dan smektit. Batuan sedimen biasanya terbentuk melalui proses pengendapan atau sedimentasi. Komposisi batu serpih yang relative halus, dengan struktur yang rumit membuat jenis batuan ini sulit diamati struktur mineral penyusunya.

Dari posko pengamatan sampel batuan yang diperoleh memiliki karakteristi batuan yang kurang baik dalam menyerap air, kerapatan yang tinggi, dan tinggkat kekerasan yang kuat dengan tekstur yang halus pada pemukaanya. Adapun sampel batuan tersebut tampak seperti gambar berikut. 


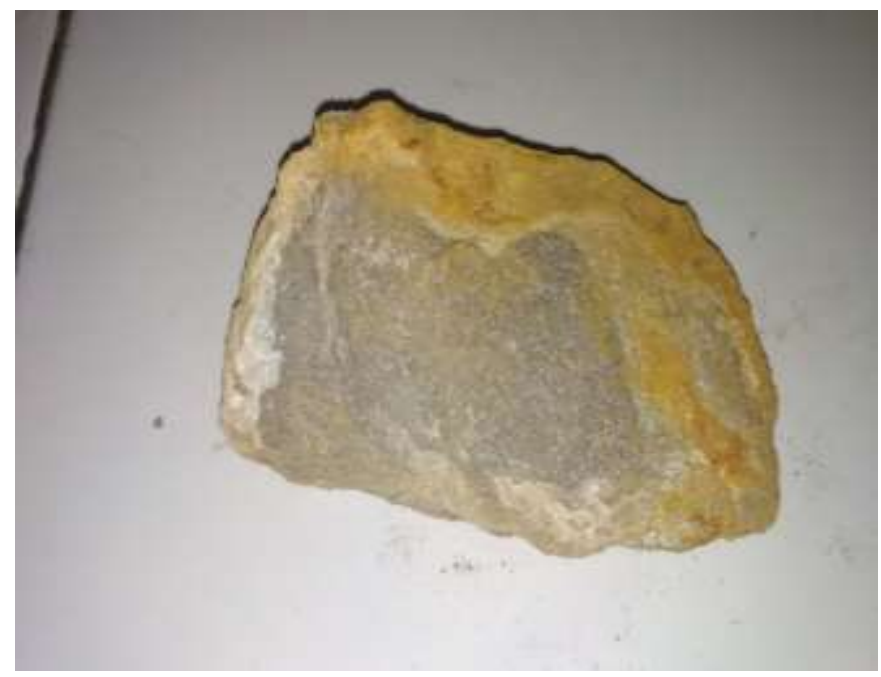

Gambar 8. Sampel batuan serpih

Dari hasil pengujian dengan air yang dilakukan batuan serpih yang diperoleh memiliki daya serap yang buruk terhadap air. Saat pemberian tekanan pada batu tersebut, untuk mengetahui tingkat kekerasan dan kerapatan mineral penyusunya diperoleh hasil yang memuaskan dimana tingkat kerapatan yang apsolut dengan kerapatan partikel yang rapat. Kekerasan absolute yang dimiliki batu serpih dipengaruhi oleh tekstur halus yang dimiliki batuan tersebut pada lapisan luarya.

\section{Batu lempung}

Batu lempung merupakan jenis batuan yang terbentuk dari proses pelapukan batuan, baik itu batuan metamorf, ataupu batuan endapan. Batu lempung memiliki sifat yang liat atau plastis. Batuan jenis ini umumnya memiliki struktur yang padat karena tersusun atas mineral yang baanyak mengandung silika.

Batu lempung yang terdapat di Alam memiliki bentuk yang berbada anatara yang satu dengan yang lainya. Batuan jenis ini sangat sulit diteliti karan kandungan mineral oksida besinya yang berupa siderite, market atau pirit. Dimana mineralmineral penyusun ini aktif secara elktrokimiawu. Pada penelitian yang dilakukan di Daerah Camba diperoleh sempel batu lempung seperti berikut. 


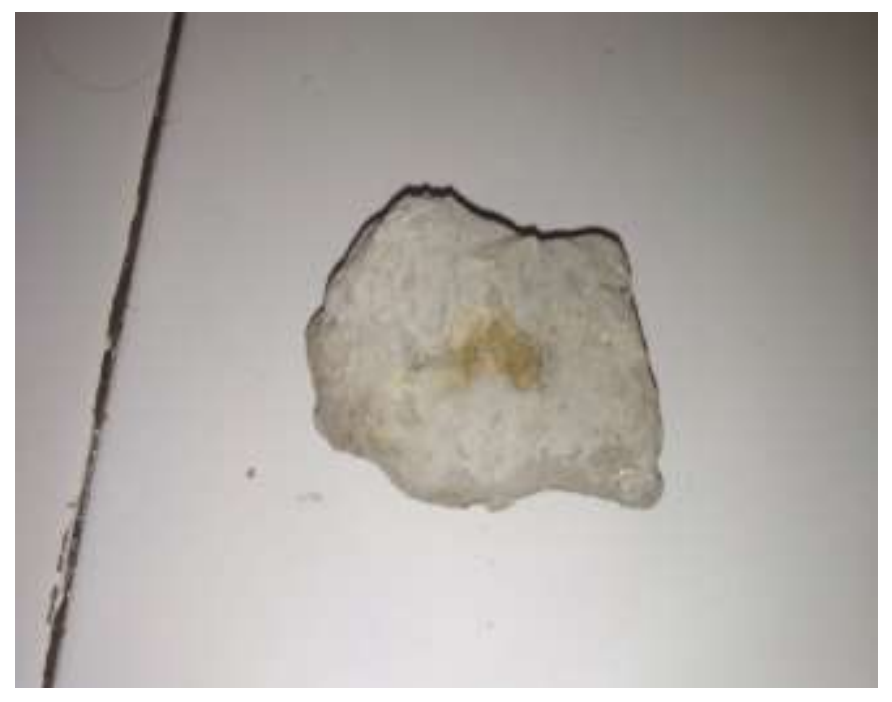

Gambar 9. Sampel batu lempung

Dari hasil pengujian yang dilakukan pada sempel yang diambil dari lokasi pengamatan. Dapat diperoleh hasil berupa tekstur sempel yang halus dengan kekerasan yang buruk, diamana sampel batu yang diujikan ini mudah hancur. Selai mudah hancur sampel ini juga banyak mengandung dan menyerap air. Batu lempung yang diperoleh pada lokasi pengamatan meruapakan jenis batu lempung yang memili tekstur mirip tanah liat.

\section{KESIMPULAN}

Kesimpulan yang dapat diperoleh dari penelitian ini yaitu:

1. Berdasarka hasil pengamatan struktur lapisa batuan di Desa Sandrego yang tampak pada bekas pengerukan tambang pasir tersusun atas batu pasir, batu gamping, batu serpih dan batu lempung.

2. Tingkat kekerasan dan daya serap batuan dipengaruhi oleh kerapatan dan besar partikelnya.

3. Penelompokan batuan yang diperoleh berdasrkan jenis dan proses pembentukannya.

\section{DAFTAR PUSTAKA}

Nurdiyanto, Boko, dkk.2011. Penentuan Tigkat Kekerasan Batuan Menggunakan Metode Seismic Refraksi. Yogyakarta: Puslitbang BMKG.

Https://ilmugeografi.com/geologi/ batu-serpih. Diakses pada tanggal 30 Juni 2019. 
Https://id.scribd.com/document/380877317/Betu-Lempung. Diakses pada tanggal 2 juli 2019

Noor Djauhari. 2009. Pengantar Geologi untuk Program Studi Teknik Geologi edisi 1. Bogor: Universitas Pakuan.

Noor Djauhari. 2009. Pengantar Geologi untuk Program Studi Teknik Geologi edisi 2. Bogor: Universitas Pakuan.

Sompotan, Armstrong F. 2012. Struktur Geologi Sulawesi. Bandung: Institut Teknologi Bandung. 